\title{
Sheep Grazing and Wildfire: Disturbance Effects on Dry Grassland Vegetation in the Western Italian Alps
}

\author{
Ginevra Nota ${ }^{1}\left(\mathbb{D}\right.$, Simone Ravetto Enri ${ }^{1, *(\mathbb{C}}$, Marco Pittarello ${ }^{1, *(\mathbb{C})}$, Alessandra Gorlier ${ }^{2}{ }^{(D)}$, \\ Giampiero Lombardi ${ }^{1,+}+$ (ib and Michele Lonati ${ }^{1,+}$ \\ 1 Department of Agricultural, Forest and Food Sciences, University of Torino, Largo Paolo Braccini 2, \\ 10095 Grugliasco (TO), Italy; ginevra.nota@unito.it (G.N.); giampiero.lombardi@unito.it (G.L.); \\ michele.lonati@unito.it (M.L.) \\ 2 School of Natural Resources and the Environment, University of Arizona, Tucson, AZ 85721, USA; \\ agorlier@arizona.edu \\ * Correspondence: simone.ravettoenri@unito.it (S.R.E.); marco.pittarello@unito.it (M.P.) \\ + These authors contributed equally to this work.
}

Citation: Nota, G.; Ravetto Enri, S.; Pittarello, M.; Gorlier, A.; Lombardi, G.; Lonati, M. Sheep Grazing and Wildfire: Disturbance Effects on Dry Grassland Vegetation in the Western Italian Alps. Agronomy 2021, 11, 6. https:/ / dx.doi.org/10.3390/agronomy11010006

Received: 19 November 2020 Accepted: 19 December 2020 Published: 23 December 2020

Publisher's Note: MDPI stays neutral with regard to jurisdictional claims in published maps and institutional affiliations.

Copyright: () 2020 by the authors. Licensee MDPI, Basel, Switzerland. This article is an open access article distributed under the terms and conditions of the Creative Commons Attribution (CC BY) license (https: / creativecommons.org/ licenses/by/4.0/).

\begin{abstract}
Land abandonment represents a major threat to the conservation of European semi-natural dry grasslands. To ensure biodiversity and habitat conservation, in this study, sheep grazing was reintroduced in abandoned Festuco-Brometea dry grasslands of a western Italian alpine valley. The experimental design included three treatments, along a gradient of increasing disturbance: (i) notgrazed, (ii) grazed, and (iii) penning areas. Unexpectedly, two years after grazing reintroduction, a wildfire hit the study area. To investigate the short-term effects of grazing and wildfire disturbances on vegetation, 62 permanent transects were monitored from 2014 to 2018 . Vegetation cover, plant diversity, and richness and abundance of three functional groups of species were analyzed through generalized linear mixed models. Grazing caused little changes in vegetation, with the greatest effects observed in penning areas: the pioneer xerothermic species group, including many rare plant species, benefited from the reduction in the litter layer and the opening of gaps in the sward induced by trampling. The wildfire led to an increase in plant diversity and to changes in plant composition: dry grassland species decreased, while pioneer xerothermic and ruderal species increased their abundance. Short-term results suggest that both disturbances may foster the conservation of alpine dry grasslands.
\end{abstract}

Keywords: biodiversity conservation; Bromus erectus; burning; night pens; priority habitats; Stipa pennata; vegetation dynamics

\section{Introduction}

Since the 1950's, socio-economic transformations have resulted in a pronounced migration of people from rural to industrialized urban areas, resulting in widespread abandonment of managed semi-natural habitats [1,2]. The negative effects of this agropastoral abandonment are widely recognized as crucial issues affecting the conservation of European semi-natural grasslands [3], and are two-fold. Firstly, the lack of biomass removal in semi-natural grasslands leads to litter accumulation and the modification of plant interspecific competition [4,5]. As a consequence, a few highly competitive grasses often increase and become dominant, while less competitive species are suppressed [6,7]. Secondly, the processes of natural succession result in a gradual but widespread shrub and tree encroachment $[6,8,9]$. Ultimately, both changes in interspecific competition and woody species encroachment lead to a dramatic decrease in plant diversity [4,10].

The interruption of management practices is a major threat for semi-natural dry grasslands, traditionally managed through extensive mowing and lenient grazing. Among them, Festuco-Brometea grasslands are valuable for their high plant diversity and richness in rare plant species [11,12] and provide habitat for several animal species, such as endangered 
birds and butterflies $[13,14]$. During the last few decades, several programs concerning the reintroduction of grazing in abandoned dry grasslands have been successfully implemented in Europe to support biodiversity and rare species conservation and to control invasive shrubs and highly competitive grass species [15-18]. Selective grazing, trampling, defecation, and heterogeneous distribution of the stocking rates enhance the sward's structural heterogeneity, thus supporting the ecological needs of a rich flora [19-21]. Moreover, biomass removal and trampling by grazing animals, which open the sward and reduce litter accumulation, play a crucial role in the germination and establishment of short-lived and light-demanding species $[16,22]$. Indeed, these species tend to disappear in abandoned grasslands because of the reduction in their competitive abilities $[4,21]$.

Most of the studies concerning the management and conservation of European dry grasslands refer to Central and Eastern Europe, e.g., [15,16,23]. In contrast, little research has focused on the management of the dry grasslands in inner-alpine valleys, despite their high conservation interest. Such species-rich communities, broadly threatened by agropastoral abandonment [24], harbor many rare elements of the steppic and Mediterranean flora [25-27]. Given the conservation interest in these plant communities, sheep grazing was reintroduced in abandoned Festuco-Brometea dry grasslands of a western Italian alpine valley in 2015, with the support of the EU LIFE program (project LIFE12 NAT/IT/000818 'Xero-grazing'). Until the mid of the 20th century, these grasslands had been traditionally maintained through extensive sheep grazing and (in the flattest areas) mowing. However, after the Second World War, this area was rapidly abandoned, and shrubs and trees progressively encroached on the grasslands, causing reduction and fragmentation of these habitats. In 2017, two years after grazing was reintroduced, an unexpected wildfire hit the entire area. Wildfires are a common disturbance in dry grasslands and contribute to keep habitats open by counteracting shrub and tree encroachment $[28,29]$. However, wildfires may turn into a severe threat for habitats and biodiversity in areas encroached by shrubs and with litter accumulation as a result of land abandonment [30]. By monitoring vegetation on permanent transects from 2014, i.e., before grazing implementation, to 2018, i.e., after the wildfire, this study provides the unique opportunity to investigate the shortterm effects of two different types of disturbance on vegetation.

The objectives of this paper were to analyze the effects of sheep grazing reintroduction, along a gradient of increasing grazing disturbance, and of the wildfire, on vegetation cover, plant diversity and richness and abundance of three functional groups of species (i.e., dry grassland, pioneer xerothermic and ruderal species) in abandoned Festuco-Brometea dry grasslands of an inner-alpine valley.

\section{Materials and Methods}

\subsection{Study Area}

The study was conducted within the Special Area of Conservation (SAC) "Xerothermic Oases of Susa Valley-Orrido of Chianocco" (SAC IT1110030), North-Western Italian Alps $\left(45^{\circ} 08^{\prime} \mathrm{N}, 7^{\circ} 06^{\prime} \mathrm{E}\right)$. The area is characterized by a xerothermic and sub-Mediterranean climate, with an average annual air temperature of $11^{\circ} \mathrm{C}$ and average annual precipitation of $670 \mathrm{~mm}$ [31]. The geological substrate consists mainly of Mesozoic limestones and dolomites.

Semi-natural dry grasslands belonging to Festuco-Brometea Br.-Bl. and Tüxen ex Br.-Bl. 1949 class and downy oak (Quercus pubescens Willd.) woodlands are the most represented plant communities in the SAC. Festuco-Brometea communities include Stipo-Poion carniolicae Br.-Bl. 1949 and Xerobromion erecti Br.-Bl. and Moor 1938 phytosociological alliances, which belong, respectively, to $6240^{*}$ and $6210^{*}$ priority habitats under the Habitat Directive 92/43/EEC [32]. Stipa pennata L. s.l., together with Festuca ovina L. s.l, and Bromus erectus Hudson, together with F. ovina s.l., are the dominant species of the Stipo-Poion carniolicae grassland type (hereafter, 'Stipo-Poion') and of the Xerobromion erecti grassland type (hereafter, 'Xerobromion'), respectively. Both grassland types host several plant species listed in National and Regional Red Lists, such as Euphorbia sulcata Loisel. [33], or protected by the 
Piedmont Regional Law (LR 32/1982), such as Brassica repanda (Willd.) DC., Echinops ritro L., and all Orchidaceae species. Moreover, some species are considered of conservation interest due to their rarity in the Alps, such as the Mediterranean species Asterolinon linumstellatum (L.) Duby, Helianthemum salicifolium (L.) Mill., Linaria simplex (Willd.) DC., Linum strictum L., and Ononis reclinata L. [34].

\subsection{Experimental Design}

The study was conducted in a 63 ha area within the SAC, consisting of 41 ha of Stipo-Poion and 22 ha of Xerobromion not managed since the 1950s (Figure 1). Altitude ranged from 550 to $1300 \mathrm{~m}$ a.s.l. and the mean slope and aspect were $30.6^{\circ}$ and $211^{\circ} \mathrm{N}$, respectively. A 43 ha area was grazed by sheep in 2015, 2016 and 2017, while a 20 ha area was left ungrazed. The presence of some wild ungulates was observed in the area, but the effects of their exploitation were negligible. Grazing was applied at low intensity (stocking rate ranging from 0.064 to $0.073 \mathrm{LU} \mathrm{ha}^{-1}$ year $^{-1}$, with 1 sheep $=0.15 \mathrm{LU}$ ) and the grazing period ranged from April to June (i.e., at the peak of plant biomass production for these grasslands). The flock consisted of 250 Bergamasca sheep managed by the shepherd in a daily routine, entailing lenient supervision during the day and confinement in temporary penning areas at night [35]. Penning areas were fenced with an electrified net that delimited an area of about 1-3 $\mathrm{m}^{2}$ sheep $^{-1}$. During each grazing year, they were moved over the pasture every 1-4 days, avoiding previously used locations. Temporary penning areas are commonly used in the Alps to prevent wolf attacks and, occasionally, to contrast shrub encroachment and improve grassland vegetation through dung deposition and trampling [8]. In this study, two penning areas in Stipo-Poion and three in Xerobromion were selected for monitoring. Each of them was used by the flock in the first grazing year (i.e., 2015) at a high stocking rate $\left(0.83 \mathrm{LU} \mathrm{ha}^{-1}\right.$ year $\left.^{-1}\right)$ and then regularly grazed in the following years. Therefore, the experimental design included three treatments for each grassland type, along a gradient of increasing disturbance: (i) not-grazed (NG), (ii) grazed (GR), and (iii) penning areas (PA).

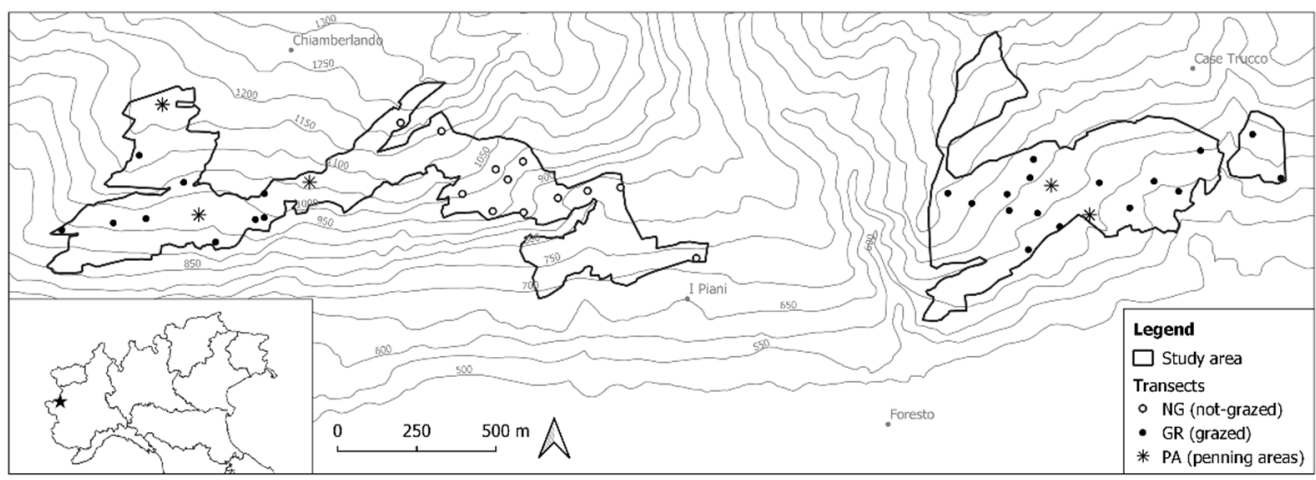

Figure 1. Map of the study area in the Western Italian Alps and location of the permanent transects. Each penning area (PA) includes five permanent transects.

From 22 to 30 October 2017, an unexpected wildfire occurred in the SAC, affecting the entire study area. To prevent soil erosion due to animal trampling and to encourage the spontaneous recovery of vegetation, grazing was not applied in 2018. The effects of the wildfire, which was assumed to have evenly hit the three grazing treatments, were assessed in the first after-fire season. 


\subsection{Vegetation Transects}

A total of 62 linear permanent transects of $12.5 \mathrm{~m}$ length was used to assess botanical composition (Table 1 and Figure 1). For both GR and NG treatments, transects were set approximately every 1.5 ha into homogeneous and representative Stipo-Poion and Xerobromion patches. In each of the five selected PA, five permanent transects were placed at a minimum distance of $5.5 \mathrm{~m}$ from each other. The ends of each transect were marked with rebars to ensure its precise re-location.

Table 1. Number of permanent transects per grassland type and treatment (NG = not-grazed, $\mathrm{GR}=$ grazed, $\mathrm{PA}=$ penning areas).

\begin{tabular}{cccc}
\hline & Stipo-Poion carniolicae & Xerobromion erecti & Total \\
\hline NG & 7 & 5 & 12 \\
GR & 17 & 8 & 25 \\
PA & 10 & 15 & 25 \\
Total & 34 & 28 & 62 \\
\hline
\end{tabular}

Vegetation transects were surveyed between April and May (i.e., at the flowering phenological stage of the dominant species) throughout four years: one year before the reintroduction of grazing $(2014, \mathrm{~T} 0)$, one $(2016, \mathrm{~T} 1)$ and two $(2017, \mathrm{~T} 2)$ years after the grazing implementation, and in the first vegetative season following the wildfire $(2018, \mathrm{~T} 3)$. In T1 and T2, transects were surveyed just before the annual grazing.

Botanical composition was assessed along each transect using the vertical pointquadrat method [36], with 50 points spaced at $25 \mathrm{~cm}$ intervals. At each point, plant species touching a steel needle were identified and recorded. Moreover, total plant cover (\%) was visually estimated within a $2 \mathrm{~m} \times 12.5 \mathrm{~m}$ area centered on the transect line (i.e., $25 \mathrm{~m}^{2}$ vegetation plot). All plant species included within the vegetation plot were also recorded to account for occasional species. Species nomenclature followed Landolt et al. [37].

\subsection{Data Analysis}

At each transect, species relative abundance (SRA) of each recorded $i$ species was calculated according to the equation of Daget and Poissonet [36]:

$$
\mathrm{SRA}_{i}=\frac{f_{i}}{\sum_{i=1}^{n} f_{i}} \times 100(\%),
$$

where $f_{i}$ is the frequency of occurrence (number of occurrences/50 points) of the species $i$.

$\mathrm{A} \mathrm{SRA}_{j}=0.3 \%$ was attributed to all occasional $j$ species found in the vegetation plot but not recorded along the transect, according to Tasser and Tappeiner [38]. As the overall $\mathrm{SRA}_{i+j}$ (hereafter SRA) was greater than $100 \%$, the $\mathrm{SRA}_{i}$ were rescaled, while maintaining $\mathrm{SRA}_{j}=0.3 \%$, to obtain a SRA equal to $100 \%$ at each plot.

At each vegetation plot, diversity was expressed in terms of total species richness, i.e., the total number of species found within the vegetation plots, and Shannon diversity index [39]. Additionally, each plant species was associated with its phytosociological optimum (at the class level) according to Aeschimann et al. [40] to identify groups of species characterized by similar ecological needs. Then, plant species were pooled into three functional groups: (i) 'dry grassland species' for plant species with ecological optimum in Festuco-Brometea and Lygeo-Stipetea classes, which correspond to the typical species of the habitats; (ii) 'pioneer xerothermic species' for plant species with ecological optimum in Koelerio-Corynephoretea and Thero-Brachypodietea classes, which include the rare Mediterranean annual species; and (iii) 'ruderal species' for plant species with ecological optimum in Agropyretea intermedii-repentis, Artemisietea vulgaris and Stellarietea mediae classes, which correspond to typical species of disturbed habitats that negatively impact on habitat conservation. Species richness and SRA of the three functional groups were 
computed for each vegetation plot. The list of all plant species and their corresponding phytosociological optimum and SRA for each treatment and year is provided in Table S1.

\subsection{Statistical Analysis}

Generalized linear mixed models (GLMMs) were used to assess the effects of grazing treatments and wildfire on grassland vegetation. All analyses were conducted separately for Stipo-Poion and Xerobromion grassland types. Total plant cover, total species richness, Shannon diversity index, and species richness and SRA of dry grassland, pioneer xerothermic, and ruderal species were considered as response variables. Treatment, year, and their interaction were set as fixed factors, while the plot was specified as a random factor to account for the repeated measure structure over the years. Tukey's post hoc tests on treatment $x$ year interactions were performed to analyze significant differences amongst treatments within each year and significant differences amongst years within each treatment. Shannon diversity index, being a continuous variable, was modeled with both normal and gamma distributions, while total species richness and richness of the three functional groups, being count variables, were modeled with both Poisson and negative binomial distributions. The model resulting in the lowest Akaike's Information Criterion value for each analysis was considered as the best fitting one and retained [41]. Total plant cover and the SRA of the functional groups, being percentage data, were rescaled between 0 and 1 to be modeled with a Beta distribution. Before the analysis, the SRA of pioneer xerothermic and ruderal species were transformed according to the formula proposed by Cribari-Neto and Zeileis [42] to rescale them and avoid 0 and 1 values, which are not allowed by Beta distribution.

The R software [43] was used for statistical analyses. GLMMs were run with the 'glmmTMB' package [44] and Tukey's post hoc tests were computed with the 'emmeans' package [45].

\section{Results}

The results of the GLMMs were scrutinized focusing on two periods of the temporal series: (i) period $\mathrm{T} 0-\mathrm{T} 2$, to assess the effects of grazing treatments, and (ii) period $\mathrm{T} 2-\mathrm{T} 3$, to assess the effects of the wildfire.

Before the implementation of grazing (T0), the average total plant cover was $74 \%$ in Stipo-Poion and $88 \%$ in Xerobromion, respectively (Figure 2a,b). During the grazing period (T0-T2), no difference in total plant cover was observed, either among treatments or among years, in both grassland types (except for a decrease in the night pens of Xerobromion at T1). After the wildfire, the total plant cover did not change in Stipo-Poion. However, in Bromus-dominated grasslands, values decreased in NG and PA, but treatments did not differ among each other after the wildfire.

A total of 237 plant species belonging to 47 botanical families were recorded in the study area (Table S1). In both grassland types, total species richness did not differ yearly among treatments and did not change within each treatment either after two years of grazing (except for an increase in the penning areas of Xerobromion) or after the wildfire (Figure $3 a, b)$. The yearly species richness of all functional groups did not differ among treatments. The richness of dry grassland species did not vary throughout time as well, while some variations within treatments were found for pioneer xerothermic and ruderal species (Figure $3 \mathrm{c}-\mathrm{h}$ ). After two years of grazing, the richness of pioneer xerothermic species increased in PA in both grassland types. In Stipa-dominated grasslands, it also increased in GR. No variations in the richness of pioneer xerothermic species were detected after the wildfire. The richness of ruderal species did not change during grazing (except for an increase in the penning areas of Stipo-Poion), but it increased after the wildfire in every treatment in Xerobromion (average increase +2.6 species). 
Stipo-Poion carniolicae

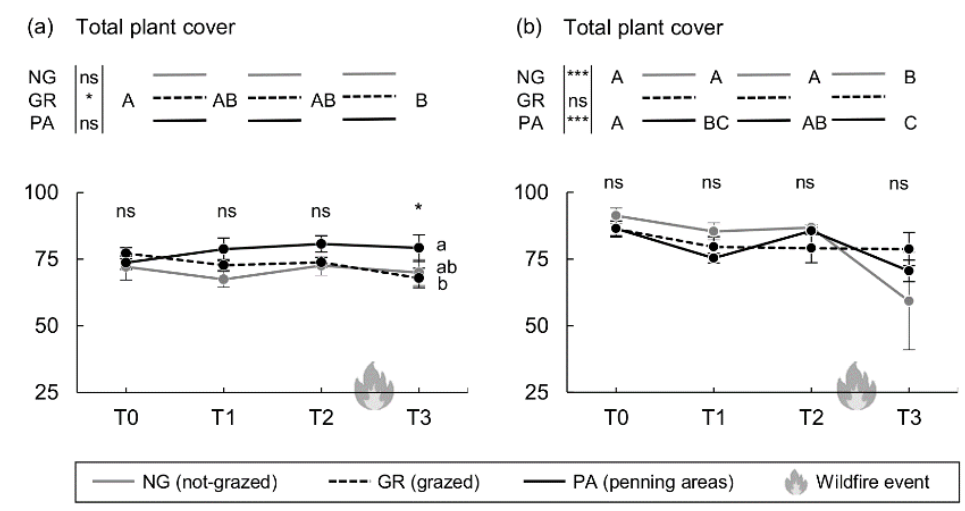

Figure 2. Results of the generalized linear mixed models performed on total plant cover in (a) Stipo-Poion carniolicae and (b) Xerobromion erecti grassland types. Uppercase letters indicate significant differences among years within each treatment while lowercase letters indicate significant differences among treatments within each year, according to Tukey's post hoc tests. Years: T0, before grazing implementation; T1 and T2, after one and two years of grazing; T3, after the wildfire. Significance levels: $\mathrm{ns}, p \geq 0.05 ;{ }^{*}, p<0.05 ;{ }^{* *}, p<0.001$.

Shannon diversity index did not differ yearly among treatments during grazing, despite a significant increase in GR in Stipo-Poion (Figure 4a,b). After the wildfire, it increased in NG in Stipo-Poion and in all treatments in Xerobromion.

The SRA of the functional groups showed opposite trends throughout time: in both grassland types, dry grassland species decreased, while pioneer xerothermic and ruderal species increased (Figure 4c-h). More specifically, the SRA of dry grassland species decreased two years after grazing in PA in both grassland types and in GR in Stipa-dominated grasslands. However, treatments did not differ at T2. A further reduction was observed in all treatments in both grassland types following the wildfire (on average, $-17.0 \%$ and $-11.9 \%$ in Stipo-Poion and Xerobromion, respectively). In contrast, the SRA of pioneer xerothermic species increased in PA and (only in Stipo-Poion) in GR during the grazing period. In the penning areas of Stipo-Poion such increase $(+12.0 \%)$ resulted in a significantly higher value compared to the other treatments at T2. After the wildfire, a further increase in the SRA of pioneer xerothermic species was recorded in all the treatments in both grassland types $(+12.2 \%$ and $+5.0 \%$ in Stipo-Poion and Xerobromion, respectively). Ruderal species SRA increased in the penning areas of both grassland types at T2, even though treatments did not differ among each other. After the wildfire, ruderal species SRA significantly increased in most treatments, i.e., NG and GR in Stipa-dominated grasslands (+6.7\%) and NG and PA in Bromus-dominated grasslands (+3.5\%). 


\section{(a) Total species richness}

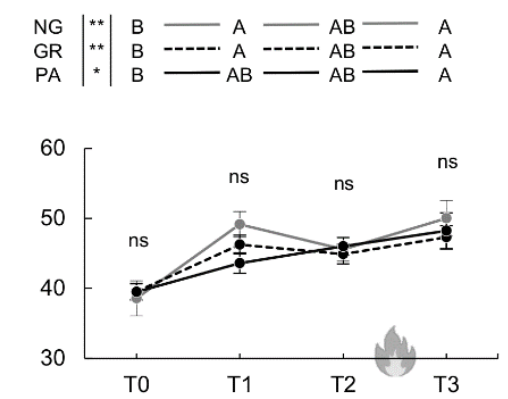

(c) Dry grassland species richness
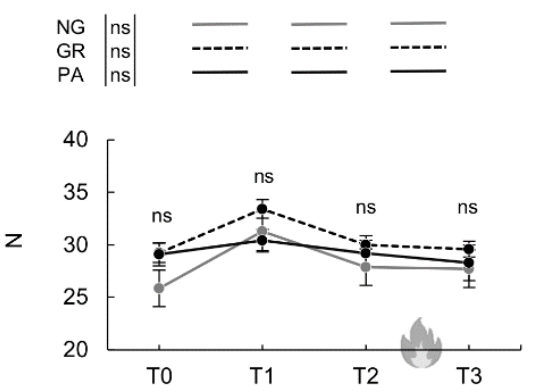

(e) Pioneer xerothermic species richness
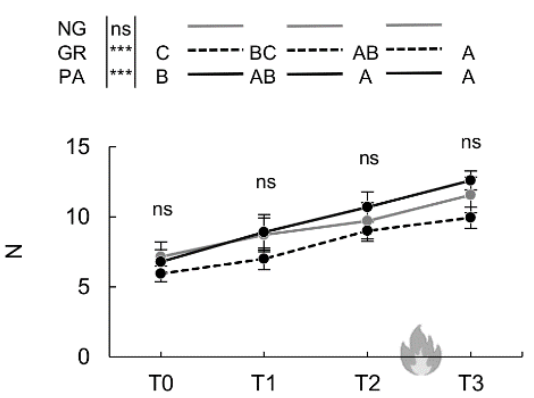

(g) Ruderal species richness
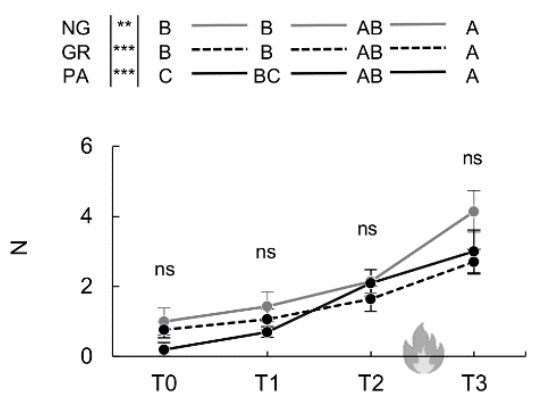

(b) Total species richness

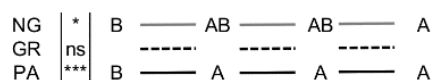

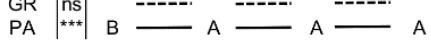

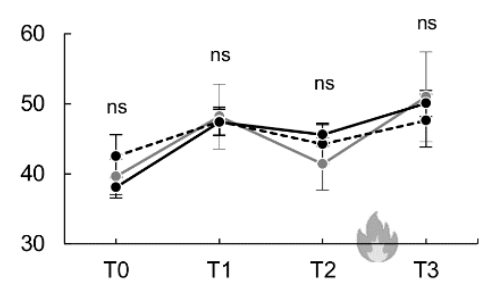

(d) Dry grassland species richness
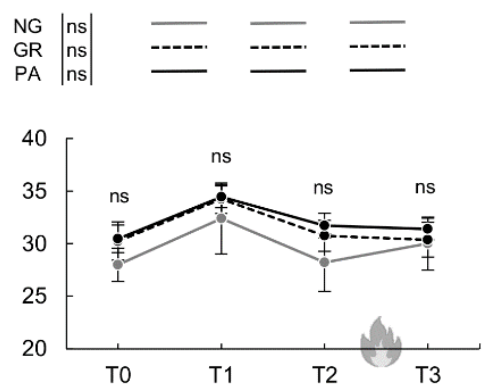

(f) Pioneer xerothermic species richness
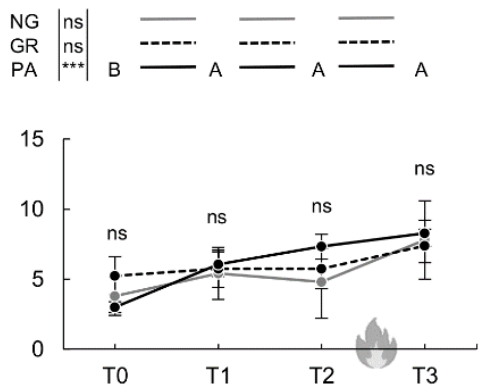

(h) Ruderal species richness
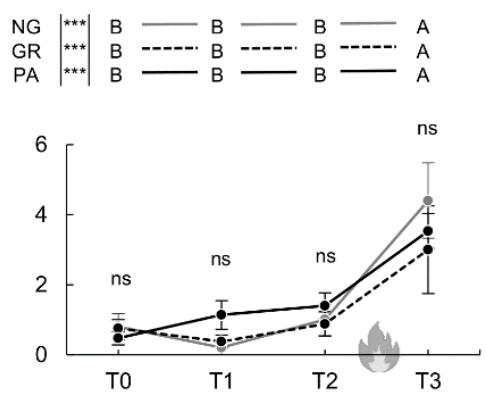

Figure 3. Results of the generalized linear mixed models performed on total species richness $(\mathbf{a}, \mathbf{b})$ and richness of dry grassland species $(\mathbf{c}, \mathbf{d})$, pioneer xerothermic species $(\mathbf{e}, \mathbf{f})$ and ruderal species (g,h) in Stipo-Poion carniolicae and Xerobromion erecti grassland types. Uppercase letters indicate significant differences among years within each treatment according to Tukey's post hoc tests. Years: T0, before grazing implementation; T1 and T2, after one and two years of grazing; T3, after the wildfire. Significance levels: ns, $p \geq 0.05 ;{ }^{*}, p<0.05 ;{ }^{* *}, p<0.01 ;{ }^{* * *}, p<0.001$. 
Stipo-Poion carniolicae

(a) Shannon diversity index

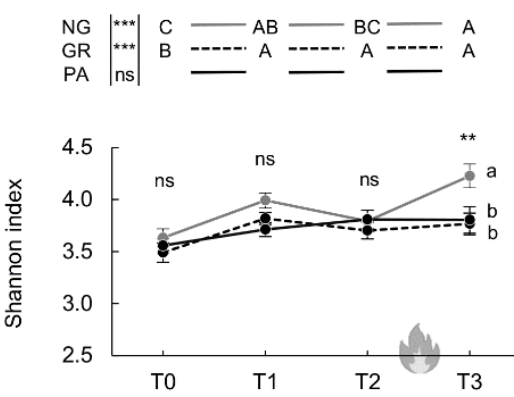

(c) SRA of dry grassland species

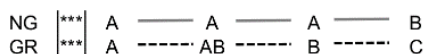

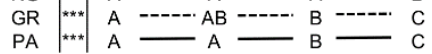

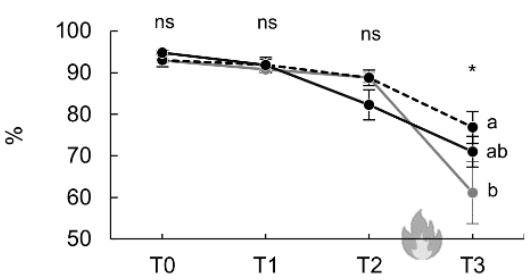

(e) SRA of pioneer xerothermic species

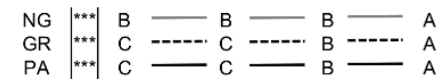

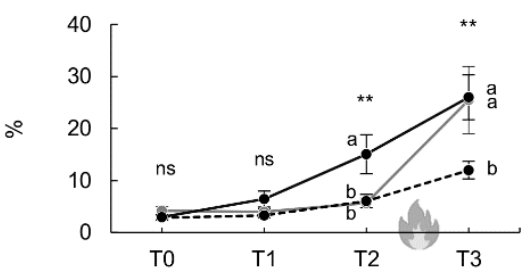

(g) SRA of ruderal species

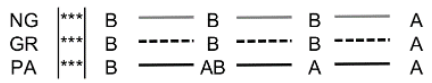

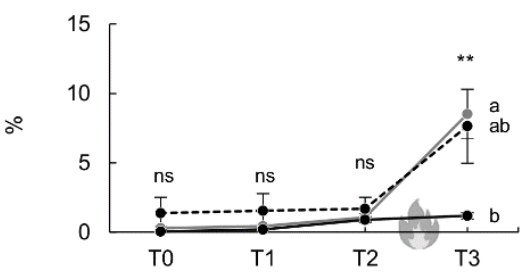

Xerobromion erecti

(b) Shannon diversity index

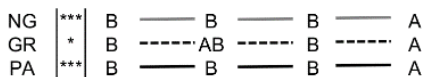

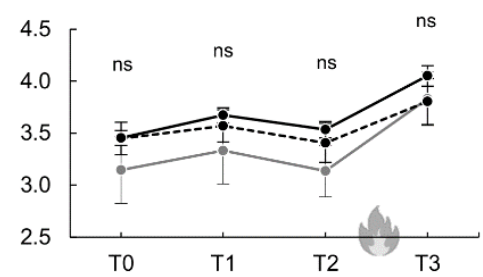

(d) SRA of dry grassland species

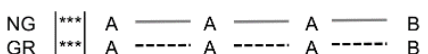

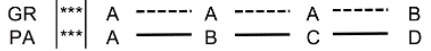

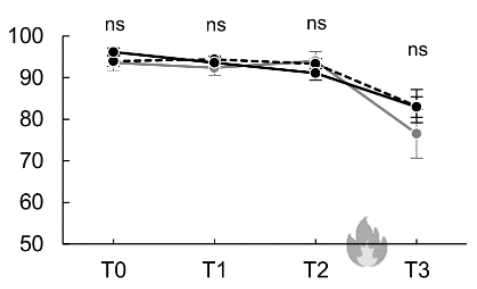

(f) SRA of pioneer xerothermic species

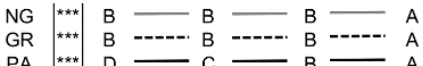

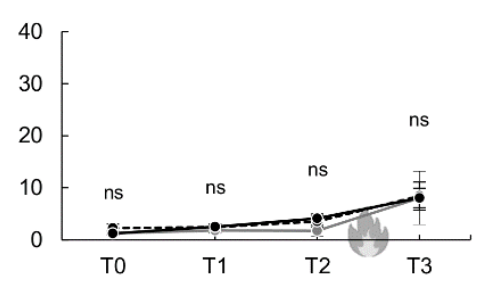

(h) SRA of ruderal species
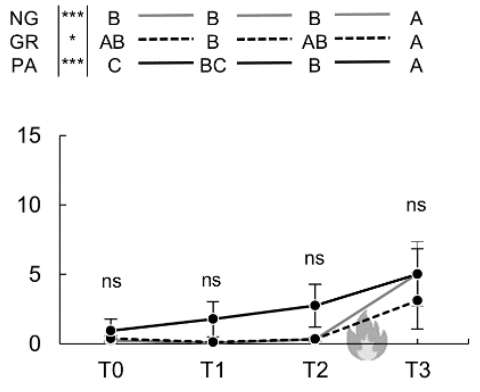

Figure 4. Results of the generalized linear mixed models performed on Shannon diversity index $(\mathbf{a}, \mathbf{b})$, SRA of dry grassland species $(\mathbf{c}, \mathbf{d})$, pioneer xerothermic species $(\mathbf{e}, \mathbf{f})$ and ruderal species $(\mathbf{g}, \mathbf{h})$ in Stipo-Poion carniolicae and Xerobromion erecti grassland types. Uppercase letters indicate significant differences among years within each treatment, while lowercase letters indicate significant differences among treatments within each year, according to Tukey's post hoc tests. Years: T0, before grazing implementation; T1 and T2, after one and two years of grazing; T3, after the wildfire. Significance levels: $\mathrm{ns}, p \geq 0.05 ;^{*}, p<0.05 ;{ }^{* *}, p<0.01 ;{ }^{* * *}, p<0.001$. 


\section{Discussion}

The reintroduction of sheep grazing in Festuco-Brometea dry grasslands of an inneralpine valley caused few changes in their vegetation in the short term. Indeed, after two years of grazing, total plant cover, species richness, and Shannon diversity index did not differ among treatments. The SRA of functional groups, instead, changed in the night pens, where dry grassland species decreased and pioneer xerothermic and, slightly, ruderal species were favored. Most of the pioneer xerothermic species are annual and light-demanding and require bare ground microsites to germinate and grow. In penning areas, their competition was probably enhanced by the opening of gaps in the sward and the reduction in the litter layer induced by trampling, which provided suitable germination microsites $[18,19,21]$. In particular, Alyssum alyssoides (L.) L., Arenaria serpyllifolia L., H. salicifolium, O. reclinata, and Petrorhagia saxifraga (L.) Link were the most abundant pioneer xerothermic species in the penning areas at the end of the grazing period (Table S1). Among these, the Mediterranean species H. salicifolium and O. reclinata are considered rare in the Alpine region.

The absence of a remarkable grazing effect on vegetation, despite defoliation, trampling and feces deposition, could be related to the harsh ecological conditions characterizing dry ecosystems (e.g., shallow soils, summer droughts, etc.). Indeed, these ecological constraints can slow down or prevent an effective vegetation response to grazing management $[46,47]$. Moreover, interannual fluctuations in temperature and precipitation could affect the plant species composition in dry grassland communities [48], and interact with and confound the effects of treatments in the short term [23,46].

Although the interannual variability could not be disentangled due to the absence of unburned control areas, the predominance of the wildfire effects on the vegetation changes between T2 and T3 was assumed. After the wildfire, total plant cover did not change in most treatments, with some reductions observed only in Xerobromion. Total species richness and the richness of functional groups were poorly affected by fire disturbance as well. The only variation concerned the recruitment of some new ruderal annuals from the seed bank, such as Ajuga chamaepitys (L.) Schreb., Chaenorrhinum minus (L.) Lange, Chenopodium album L., and Turritis glabra L. (Table S1). In agreement with the results of Valkó et al. [49] and Vidaller et al. [50], instead, the Shannon diversity index was enhanced by the wildfire (especially in Xerobromion), resulting in a much more balanced proportion of species. Such an effect reflected the trend of the SRA of functional groups: in both grassland types, dominant dry grassland species decreased, while those groups that were poorly represented before the wildfire (i.e., pioneer xerothermic and ruderal species) increased their relative abundance. Specifically, in both grassland types, the pioneer xerothermic species accounting for most of the SRA after the wildfire were A. alyssoides, A. serpyllifolia, Echium vulgare L., P. saxifraga, and the rare Mediterranean species L. simplex and O. reclinata. The species accounting for most of the SRA of ruderal species were Carduus nutans L., Elymus repens (L.) Gould, Erodium cicutarium (L.) L'Hér., Reseda lutea L., and R. phyteuma L. (Table S1). These pioneer xerothermic and ruderal species probably benefited from both the litter removal and the damage caused by burning to perennial species (e.g., dominant tussock-forming grasses belonging to the dry grassland functional group), that created bare ground areas suitable for their germination and propagation [28,49]. The increase in E. repens after the wildfire can be related to its stoloniferous life form, as highlighted also by Ruprecht et al. [23]. The occurrence of both pioneer xerothermic and ruderal species in the first stages of a post-fire chronosequence was also reported by Lonati et al. [51] in Scots pine forests of an inner-alpine dry valley in the Western Italian Alps.

The positive effects on biodiversity and pioneer xerothermic species, and the substantial recovery of plant cover in the first after-fire season, might be taken into account in case of application of prescribed burning for the conservation of these grasslands. This practice has been proposed as a cost-effective management tool for the maintenance of different open habitats, such as dry grasslands and heathlands [30,50,52], even if some authors highlighted possible negative outcomes on habitat conservation status [53]. Still, in most 
of the European countries, the implementation of prescribed burning may be laborious because of strict regulations.

\section{Conclusions}

This study showed that the plant biodiversity of Festuco-Brometea dry grasslands of an inner-alpine valley was preserved after both grazing and burning disturbances. The main effects on vegetation concerned the abundance of functional groups rather than their species richness, and the magnitude of such effects was greater after the wildfire than in the previous grazing period. Changes in plant composition intensified along the gradient of increasing grazing disturbance and suggested a similar pattern under both burning and grazing disturbances, i.e., a decrease in dry grassland species and an increase in pioneer xerothermic and ruderal species. Future studies should be performed in a longer time span, to assess long-term vegetation responses and disentangle treatment effects from climatic influences.

Supplementary Materials: The following are available online at https://www.mdpi.com/2073-4 395/11/1/6/s1, Table S1: Plant species recorded in each treatment and year with corresponding phytosociological optimum and average species relative abundance, File S1: R codes used to run the generalized linear mixed models.

Author Contributions: Conceptualization, M.L. and G.L.; methodology, S.R.E., M.P., M.L. and G.L.; formal analysis, G.N.; investigation, G.N., S.R.E., M.P., A.G., M.L. and G.L.; writing—original draft preparation, G.N.; writing—review and editing, S.R.E., M.P., A.G., M.L. and G.L.; supervision, A.G., M.L. and G.L.; project administration, M.L. and G.L.; funding acquisition, M.L. and G.L. All authors have read and agreed to the published version of the manuscript.

Funding: This research was funded by the EC-LIFE program, project LIFE12 NAT/IT/000818 'Xerograzing' (Principal Investigator Prof. Giampiero Lombardi).

Data Availability Statement: The database is available upon request to the corresponding authors.

Acknowledgments: The authors gratefully thank the 'Ente di gestione delle aree protette delle Alpi Cozie' (Coordinating Beneficiary) and the farmer Franco Pia for their constant support and the provision of the flock. Special thanks are extended to Andrea Ala, Davide Barberis, Francesca Colozza, Federico Lingua, Elisa Perotti, Elena Quaglia, Elisa Treves, and Gabriel Trogolo for their help with the fieldwork.

Conflicts of Interest: The authors declare no conflict of interest.

\section{References}

1. Poschlod, P.; Wallis De Vries, M.F. The historical and socioeconomic perspective of calcareous grasslands-lessons from the distant and recent past. Biol. Conserv. 2002, 104, 361-376. [CrossRef]

2. Prévosto, B.; Kuiters, L.; Bernhardt-Römermann, M.; Dölle, M.; Schmidt, W.; Hoffmann, M.; Van Uytvanck, J.; Bohner, A.; Kreiner, D.; Stadler, J.; et al. Impacts of Land Abandonment on Vegetation: Successional Pathways in European Habitats. Folia Geobot. 2011, 46, 303-325. [CrossRef]

3. Valkó, O.; Venn, S.; Żmihorski, M.; Biurrun, I.; Labadessa, R.; Loos, J. The challenge of abandonment for the sustainable management of Palaearctic natural and semi-natural grasslands. Hacquetia 2018, 17, 5-16. [CrossRef]

4. Bohner, A.; Karrer, J.; Walcher, R.; Brandl, D.; Michel, K.; Arnberger, A.; Frank, T.; Zaller, J.G. Ecological responses of semi-natural grasslands to abandonment: Case studies in three mountain regions in the Eastern Alps. Folia Geobot. 2020, 54, 211-225. [CrossRef]

5. Enyedi, Z.M.; Ruprecht, E.; Deák, M. Long-term effects of the abandonment of grazing on steppe-like grasslands. Appl. Veg. Sci. 2008, 11, 55-62. [CrossRef]

6. Giarrizzo, E.; Burrascano, S.; Chiti, T.; de Bello, F.; Lepš, J.; Zavattero, L.; Blasi, C. Re-visiting historical semi-natural grasslands in the Apennines to assess patterns of changes in species composition and functional traits. Appl. Veg. Sci. 2017, 20, 247-258. [CrossRef]

7. Hegedüšová, K.; Senko, D. Successional changes of dry grasslands in southwestern Slovakia after 46 years of abandonment. Plant Biosyst. 2011, 145, 666-687. [CrossRef]

8. Pittarello, M.; Probo, M.; Lonati, M.; Lombardi, G. Restoration of sub-alpine shrub-encroached grasslands through pastoral practices: Effects on vegetation structure and botanical composition. Appl. Veg. Sci. 2016, 19, 381-390. [CrossRef] 
9. Orlandi, S.; Probo, M.; Sitzia, T.; Trentanovi, G.; Garbarino, M.; Lombardi, G.; Lonati, M. Environmental and land use determinants of grassland patch diversity in the western and eastern Alps under agro-pastoral abandonment. Biodivers. Conserv. 2016, 25, 275-293. [CrossRef]

10. Görzen, E.; Borisova, K.; Fenesi, A.; Ruprecht, E.; Donath, T.W. Effects of woody species encroachment and fire on vegetation and the soil seed bank in dry grasslands of Transylvania. Appl. Veg. Sci. 2019, 22, 409-422. [CrossRef]

11. Dengler, J.; Becker, T.; Ruprecht, E.; Szabó, A.; Becker, U.; Beldean, M.; Bita-Nicolae, C.; Dolnik, C.; Goia, I.; Peyrat, J.; et al. Festuco-Brometea communities of the Transylvanian Plateau (Romania)—A preliminary overview on syntaxonomy, ecology, and biodiversity. Tuexenia 2012, 32, 319-359.

12. Wilson, J.B.; Peet, R.K.; Dengler, J.; Pärtel, M. Plant species richness: The world records. J. Veg. Sci. 2012, 23, 796-802. [CrossRef]

13. Calaciura, B.; Spinelli, O. Management of Natura 2000 Habitats. 6210 Semi-Natural Dry Grasslands and Scrubland Facies on Calcareous Substrates (Festuco-Brometalia) (“Important Orchid Sites); European Commission: Brussels, Belgium, 2008.

14. WallisDeVries, M.F.; Van Swaay, C.A.M. Grasslands as habitats for butterflies in Europe. In Grasslands in Europe of High Nature Value; Venn, P., Jefferson, R., de Smidt, J., van der Straaten, J., Eds.; KNNV Publishing: Utrecht, The Netherlands, 2009; pp. 27-34.

15. Dostálek, J.; Frantík, T. Dry grassland plant diversity conservation using low-intensity sheep and goat grazing management: Case study in Prague (Czech Republic). Biodivers. Conserv. 2008, 17, 1439-1454. [CrossRef]

16. Elias, D.; Hölzel, N.; Tischew, S. Positive effects of goat pasturing on the threatened spring geophyte Gagea bohemica in formerly abandoned dry grasslands. Flora 2018, 249, 53-59. [CrossRef]

17. Elias, D.; Tischew, S. Goat pasturing-A biological solution to counteract shrub encroachment on abandoned dry grasslands in Central Europe? Agric. Ecosyst. Environ. 2016, 234, 98-106. [CrossRef]

18. Schwabe, A.; Süss, K.; Storm, C. What are the long-term effects of livestock grazing in steppic sandy grassland with high conservation value? Results from a 12-year field study. Tuexenia 2013, 33, 189-212.

19. Godó, L.; Valkó, O.; Tóthmérész, B.; Török, P.; Kelemen, A.; Deák, B. Scale-dependent effects of grazing on the species richness of alkaline and sand grasslands. Tuexenia 2017, 37, 229-246. [CrossRef]

20. Pittarello, M.; Gorlier, A.; Lombardi, G.; Lonati, M. Plant species selection by sheep in semi-natural dry grasslands extensively grazed in the south-western Italian Alps. Rangel. J. 2017, 39, 123-131. [CrossRef]

21. Rupprecht, D.; Gilhaus, K.; Hölzel, N. Effects of year-round grazing on the vegetation of nutrient-poor grass- and heathlandsEvidence from a large-scale survey. Agric. Ecosyst. Environ. 2016, 234, 16-22. [CrossRef]

22. Ruprecht, E.; Enyedi, M.Z.; Eckstein, R.L.; Donath, T.W. Restorative removal of plant litter and vegetation 40 years after abandonment enhances re-emergence of steppe grassland vegetation. Biol. Conserv. 2010, 143, 449-456. [CrossRef]

23. Ruprecht, E.; Enyedi, M.Z.; Szabó, A.; Fenesi, A. Biomass removal by clipping and raking vs burning for the restoration of abandoned Stipa-dominated European steppe-like grassland. Appl. Veg. Sci. 2016, 19, 78-88. [CrossRef]

24. Schwabe, A.; Kratochwil, A. Festucetalia valesiacae communities and xerothermic vegetation complexes in the Central Alps related to environmental factors. Phytocoenologia 2004, 34, 329-446. [CrossRef]

25. Braun-Blanquet, J. Die Inneralpine Trockenvegetation; Fischer: Stuttgart, Germany, 1961.

26. Dengler, J.; Widmer, S.; Staubli, E.; Babbi, M.; Gehler, J.; Hepenstrick, D.; Bergamini, A.; Billeter, R.; Boch, S.; Rohrer, S.; et al. Dry grasslands of the central valleys of the Alps from a European perspective: The example of Ausserberg (Valais, Switzerland). Hacquetia 2019, 18, 155-177. [CrossRef]

27. Royer, J.M. Synthèse eurosibérienne, phytosociologique et phytogéographique de la classe des Festuco-Brometea. Diss. Bot. 1991, $178,1-296$.

28. Deák, B.; Valkó, O.; Török, P.; Végvári, Z.; Hartel, T.; Schmotzer, A.; Kapocsi, I.; Tóthmérész, B. Grassland fires in HungaryExperiences of nature conservationists on the effects of fire on biodiversity. Appl. Ecol. Environ. Res. 2014, 12, $267-283$. [CrossRef]

29. Stavi, I. Wildfires in Grasslands and Shrublands: A Review of Impacts on Vegetation, Soil, Hydrology, and Geomorphology. Water 2019, 11, 1042. [CrossRef]

30. Valkó, O.; Török, P.; Deák, B.; Tóthmérész, B. Review: Prospects and limitations of prescribed burning as a management tool in European grasslands. Basic Appl. Ecol. 2014, 15, 26-33. [CrossRef]

31. Biancotti, A.; Bellardone, G.; Bovo, S.; Cagnazzi, B.; Giacomelli, L.; Marchisio, C. Distribuzione Regionale di Piogge e Temperature; Regione Piemonte: Torino, Italy, 1998.

32. Biondi, E.; Blasi, C.; Burrascano, S.; Casavecchia, S.; Copiz, R.; Del Vico, E.; Galdenzi, D.; Gigante, D.; Lasen, C.; Spampinato, G.; et al. Manuale Italiano di Interpretazione Degli Habitat Della Direttiva 92/43/CEE; Società Botanica Italiana, Ministero dell'Ambiente e della Tutela del Territorio e del Mare: Firenze, Italy, 2009.

33. Conti, F.; Manzi, A.; Pedrotti, F. Liste Rosse Regionali Delle Piante d'Italia; WWF Italia, Società Botanica Italiana, Università degli Studi di Camerino: Camerino (MC), Firenze, Italy, 1997.

34. Pignatti, S.; La Rosa, M.; Guarino, R. Flora D'italia, 2nd ed.; Edagricole di New Business Media: Bologna, Italy, 2017.

35. Ravetto Enri, S.; Gorlier, A.; Nota, G.; Pittarello, M.; Lombardi, G.; Lonati, M. Distance from Night Penning Areas as an Effective Proxy to Estimate Site Use Intensity by Grazing Sheep in the Alps. Agronomy 2019, 9, 333. [CrossRef]

36. Daget, P.; Poissonet, J. Une méthode d'analyse phytologique des prairies. Ann. Agron. 1971, 22, 5-41. 
37. Landolt, E.; Bäumler, B.; Erhardt, A.; Hegg, O.; Klötzli, F.; Lämmler, W.; Nobis, M.; Rudmann-Maurer, K.; Schweingruber, F.; Theurillat, J.-P. Flora Indicativa-Ecological Indicator Values and Biological Attributes of the Flora of Switzerland and the Alps; Haupt Verlag: Bern, Switzerland, 2010.

38. Tasser, E.; Tappeiner, U. New model to predict rooting in diverse plant community compositions. Ecol. Model. 2005, 185, 195-211. [CrossRef]

39. Magurran, A.E. Ecological Diversity and Its Measurement; Princeton University Press: Princeton, NJ, USA, 1988.

40. Aeschimann, D.; Lauber, K.; Moser, D.M.; Theurillat, J.-P. Flora Alpina; Zanichelli: Bologna, Italy, 2004.

41. Zuur, A.F.; Ieno, E.N.; Walker, N.J.; Saveliev, A.A.; Smith, G.M. Mixed Effects Models and Extensions in Ecology with R; Springer: New York, NY, USA, 2009.

42. Cribari-Neto, F.; Zeileis, A. Beta Regression in R. J. Stat. Softw. 2010, 34. [CrossRef]

43. R Core Team R: A Language and Environment for Statistical Computing; R Foundation for Statistical Computing: Vienna, Austria, 2018.

44. Brooks, M.E.; Kristensen, K.; van Benthem, K.J.; Magnusson, A.; Berg, C.W.; Nielsen, A.; Skaug, H.J.; Machler, M.; Bolker, B.M. Glmm TMB balances speed and flexibility among packages for zero-inflated generalized linear mixed modeling. $R$ J. 2017, 9 , 378-400. [CrossRef]

45. Lenth, R. Emmeans: Estimated Marginal Means, aka Least-Squares Means, R Package Version 1.3.0; 2018. Available online: https: / /CRAN.R-project.org/package=emmeans (accessed on 10 September 2019).

46. Sternberg, M.; Gutman, M.; Perevolotsky, A.; Ungar, E.D.; Kigel, J. Vegetation response to grazing management in a Mediterranean herbaceous community: A functional group approach. J. Appl. Ecol. 2000, 37, 224-237. [CrossRef]

47. Török, P.; Valkó, O.; Deák, B.; Kelemen, A.; Tóthmérész, B. Traditional Cattle Grazing in a Mosaic Alkali Landscape: Effects on Grassland Biodiversity along a Moisture Gradient. PLoS ONE 2014, 9. [CrossRef] [PubMed]

48. Dostálek, J.; Frantík, T. Response of dry grassland vegetation to fluctuations in weather conditions: A 9-year case study in Prague (Czech Republic). Biologia 2011, 66, 837-847. [CrossRef]

49. Valkó, O.; Deák, B.; Magura, T.; Török, P.; Kelemen, A.; Tóth, K.; Horváth, R.; Nagy, D.D.; Debnár, Z.; Zsigrai, G.; et al. Supporting biodiversity by prescribed burning in grasslands-A multi-taxa approach. Sci. Total Environ. 2016, 572, 1377-1384. [CrossRef] [PubMed]

50. Vidaller, C.; Dutoit, T.; Ramone, H.; Bischoff, A. Fire increases the reproduction of the dominant grass Brachypodium retusum and Mediterranean steppe diversity in a combined burning and grazing experiment. Appl. Veg. Sci. 2019, 22, 127-137. [CrossRef]

51. Lonati, M.; Vacchiano, G.; Berretti, R.; Motta, R. Effect of stand-replacing fires on Mediterranean plant species in their marginal alpine range. Alp. Bot. 2013, 123, 123-133. [CrossRef]

52. Ascoli, D.; Lonati, M.; Marzano, R.; Bovio, G.; Cavallero, A.; Lombardi, G. Prescribed burning and browsing to control tree encroachment in southern European heathlands. For. Ecol. Manag. 2013, 289, 69-77. [CrossRef]

53. Silva, V.; Catry, F.X.; Fernandes, P.M.; Rego, F.C.; Bugalho, M.N. Trade-offs between fire hazard reduction and conservation in a Natura 2000 shrub-grassland mosaic. Appl. Veg. Sci. 2020, 23, 39-52. [CrossRef] 